\title{
Legal responsibility in an entangled world
}

\author{
Julia Eckert and Laura Knöpfel
}

\begin{abstract}
Responsibility and accountability in entangled global relations are negotiated across jurisdictional boundaries, localities and scales of legality. In this special issue, we trace struggles for corporate accountability from extraction sites in Ecuador, Colombia and Peru to an abandoned asbestos factory in Italy. We enquire into the gap between the legal institutions which govern attributions of responsibility in procedural, tort and corporate laws, lived experiences of harm connected to transnational business activities and moral expectations of responsibility in global relations. In the struggles for justice discussed in this special issue, we detect potential ways of rethinking ascriptions of responsibility to reflect the deep entanglements of our economies.
\end{abstract}

Keywords: Legal responsibility, global capitalism, corporate accountability, mobilisation of law, juridification

Harm in the context of global capitalism is locally felt but transnational in the process of its production. In this special issue, we turn to struggles for corporate accountability to trace possible means of attributing responsibility in ways that reflect how global entanglements cross existing jurisdictional boundaries, transgress distinctions between legal fields and connect actors, places, and jurisdictions at different scales. We read these struggles as an expression of the disconnect between moral expectations and legal regulations within contemporary global capitalism. We posit that established legal institutions do not adequately reflect how harm is produced in border-transcending networks of extraction, production, trade, and consumption, and they also do not pay heed to matters of power and capacity in these complex processes. Law partitions entangled global relations into national units determined by domestic corporate and contract law. While most states recognize and enforce foreign law for contracts and financial collateral (Pistor 2019: 7), laws that regulate responsibility do not travel well, and 
are 'cut' by jurisdictional and temporal limitations. Such a partitioning of global economic relations into neat units of potential responsibility hampers a social legal imagining of global value chains as integrated, border-transcending economic entities and social institutions (Sobel-Read 2014). Hence, James Ferguson once aptly asked '[h]ow to identify a unit of responsibility, in a fiendishly complex, multiplylayered and decidedly trans-national apparatus of harm-production?' (2012: 560). In short, the depth and breadth of global entanglements are beyond law's conceptual grasp.

The mismatch between the structure of global production, harm and law culminates in an 'organized irresponsibility' that Ulrich Beck identified as one of the central features of today's 'global risk society' (Beck 1999). Such organized irresponsibility is not a by-product of global value chains, but a central reason for their profitability. In fact, legal concepts and principles have enabled and reinforced processes of 'disembedding' - regulatory, spatial, and temporal dislocation - economic relations from their societal contexts (Joerges and Falke 2011). Existing legal instruments, as Marilyn Strathern once put it, 'cut' through the extensive entanglements in which harms are produced. ${ }^{1}$ Regardless of whether we look at provisions of criminal or civil law, legal tools are employed in a manner that diverts the focus away from core issues of corporate capitalism. By concentrating attention on individual injuries, existing instruments leave unaddressed the regulations that provide for the structural conditions of possibility of such injuries - such as investment and tax regimes. Moreover, they rely on concepts of responsibility that privilege notions of immediate causation and intent, which are inadequate to tackle the complex chains of distributed agency, in which harms are produced and the distribution of capacities that could remedy both the production of harm and the effective harms. These are the 'legal black holes' (Mann 2018) that current legal institutions leave us to grapple with, where injuries, damages, and losses have no response in law, and the people harmed are left without any means of remedy.

These legal black holes of responsibility, we contend, are challenged by the mobilization of law 'from below' when people apply existing legal norms to their situations to claim an effective attribution of responsibility to those who would have the capacity to do otherwise. Struggles around corporate responsibility challenge legal fictions of international and national law such as the sovereign nation state, the separate corporate person, and freedom of contract, since these fictions bear little resemblance to the 'assemblages' (Ong and Collier 2005) that 
create our global entanglements. Such struggles call for a reconfiguration of relations between the various actors participating in the value chains of global capitalism and a (re)location of responsibility where the capacity for change, and the reasons and 'root causes' (Marks 2011) of harmful activities lie. ${ }^{2}$ We are interested in the shifts that struggles through law can engender in the 'cuts' liberal law creates in deeply entangled circumstances - the techniques, processes and reasonings by means of which moral ideas about the responsibilities of corporations, governments, and other actors participating in entangled relations, and particularly in the commodity chains that span the globe, become or are turned into legal understandings.

The contributions to this special issue thus explore how people experiencing harm related to the activities of multinational corporations struggle to define the kinds of responsibilities that are at stake in the entangled situations they face, and how they strive for justice. We examine how local struggles for corporate responsibility relate to the existing regulatory answers in national and international law and how the available legal tools shape aspirations and disappointments. We particularly observe how these struggles often call into question extant legal institutions in the very act of employing them. What is at issue is how, against a background of changing perceptions of global entanglement, moral understandings of responsibility enter into struggles about legal responsibility in places where international investments are made, challenging jurisdictional boundaries and the spatio-temporal order within which responsibility is legally conceptualized.

Three questions stand at the centre of the articles collected in this special issue. First, how do reflections on our entanglements in global relations alter narratives about retrospective and prospective, moral and legal responsibilities and transgress the existing limits of laws of tort and contractual liability and the criminal responsibility of corporations and states? The contributors here consider which actors are given prime responsibility and what new conundrums ensue from shifts in claims of responsibility away from states towards corporations. Second, what promises of justice inhere in the different legal instruments used in juridification processes, and in the use of law in general, and how do these shape expectations, hopes and disappointments? Third, what specific limits do the various legal instruments that are introduced to regulate corporate responsibility impose on what can be named as an injury? Does juridification engender a depoliticization where that which can be addressed is reduced to available legal instruments, while other forms of suffering and even the structural possibilities of harm 
are lost from view? Or is it part of the re-politicization of the global economy?

The contributions to this issue cover various jurisdictions, including Italy, England, Peru, Ecuador and Colombia, and, more importantly, they are concerned with different legal fields and moments in time at which law becomes relevant to communities, activists, and corporations. The articles address how the institutions of civil liability, criminal liability, and the state's duty to protect are mobilized in these struggles for justice, thereby shedding light on a range of opportunities for and limits on the ability of criminal, civil, and public law to ascribe responsibility and deal with the spatial and temporal dimensions of harm.

\section{Mobilizing law for global justice}

The past two decades have seen much regulatory activity in national parliaments and courts, at the EU and UN and within other international organizations (Nolan and Baumann-Pauly 2016; Palombo 2020; Rodríquez-Garavito 2017; Ruggie 2007, 2013). ${ }^{3}$ Transnational advocacy networks of local and international NGOs have explored the possibilities and limits of domestic tort, criminal and human rights laws in transnational lawsuits against parent corporations for the conduct of their subsidiaries and affiliates (see also Lindt this issue; for an overview of the lawsuits in Europe, see Marx et al. 2019). ${ }^{4}$ Civil society organizations and NGOs have pressed for legislative changes in home state jurisdictions, to ensure, for example, that corporations are subject to human rights due diligence obligations (Burgos 2012). International organizations have developed guidelines and frameworks to clarify and govern the relationship between business and human rights, the most significant of which are the UN Guiding Principles on Business and Human Rights adopted by the UN Human Rights Council in 2011. ${ }^{5}$ The emerging regulatory field, which encompasses legal institutions of responsibility and accountability ranging from tort and contract law to customary international human rights law, is a hybrid conglomeration of private codes of conduct and national and international laws and regulations.

The belief in the potential of law to bring about change persists despite all evidence that the 'root causes' (Marks 2011) of harm are left unaffected. Indeed, many of the attempts to hold corporations accountable for harms that occur in relation to their economic activities raise hopes and expectations they do not fulfil. The majority of transnational suits 
against parent corporations for harms along their supply chains have not been decided on the merits. They have either stumbled at jurisdictional hurdles or ended in out-of-court settlements. There are various reasons for this, foremost among them the many obstacles that stand in the way of plaintiffs successfully suing multinational corporations, ranging from access to courts to information and financial resources to jurisdictional boundaries to the corporate veil, as a large body of research has shown (Marx et al. 2019; Skinner et al. 2013; Zerk 2014;). The turn to law has been judged futile and even de-politicizing 'legal fetishism' (Comaroff and Comaroff 2003), affirming the political order that underlies harm.

Yet in situations where 'politics proper' does not succeed, when demonstrations are put down with violence, as in the case described by Angela Lindt in this issue, or when far-reaching agreements between governments and corporations are concluded in the absence of democratic controls, in short, when the odds are stacked too high against those without financial means or political clout, law might nonetheless turn out to be the only means available. It might be a weak tool, and it might fail. However, as Stuart Kirsch holds, the threat of litigation is 'one of the few sources of regulatory power available in a neoliberal world order' (Kirsch 2014: 85). The mobilization of law thus appears as a means of doing politics, rather than in opposition to it. Inasmuch as these struggles for law strive to formulate and even establish other laws, to shift the prevailing cuts made by liberal law and to transform institutions to better reflect the relations that shape our current world, they might also re-politicize realms of interaction that have been de-politicized by current economic ideologies.

The mobilizations of law to address the harms and damages suffered as a consequence of the economic activities of multinational corporations that we observe seek justice and prevention; these are the two concerns that those engaged in fighting against harmful activities of multinational corporations express. What inspires these mobilizations of law is the hope of finding effective remedy. This requires two things: the appropriate allocation of responsibility to those who are the reason for (rather than merely the cause of) harms, and who have the capacity to change the way things are done. Those who are affected by corporate harm do not perceive those who immediately commit an act of harm to bear sole responsibility for remedying the situation. They look as well to those on behalf of whose interests and for whose benefit the harms are committed. It is their hope, however faint, that the law could provide the means to hold globally operating corporations 
accountable for some of the harmful effects of their operations, where other means are not available; it is a hope that the law might balance the extreme asymmetries between such corporations and the people affected adversely by their activities. It is thus a belief in law's promise of equalizing unequal power relations that inspires the 'juridification of protest' (Eckert et al. 2012) that we observe and the belief in law's promise of justice (Lemaitre 2007).

For many plaintiffs, justice is closely connected to the attribution of 'guilt'. This becomes particularly evident in the articles by Angela Lindt and David Loher. However, the settlements that often replace trials in transnational litigation concerning corporate responsibility often do not bring about a judgement and thus do not state where fault lies. Lindt and Loher both show how out-of-court settlements individualize damage and fault. The individualization occurs with regard to the perpetrator as well as the victim, singling out specific, individual 'units of responsibility' as well as 'units of suffering' according to the available legal instruments, which, for functional reasons, have a narrow conception of both perpetrator and victim. In the case studied by Lindt, the compensation payments made to individual claimants under the settlement led to disputes and social tensions within the affected communities about the distribution of this money. By focussing on individual remedies, attention is also distracted from the complex causes of harm. Lindt discusses how disappointment with transnational lawsuits led victims to return to local and national legal avenues. Here we see how conceptions of responsibility are influenced by the legal process itself, as the focus on the individual local perpetrators of harm drew attention away from the corporate centre of the global value chain. Thus, the fragmentation of the value chain established by law and the immediate experience of injury converged when the entangled processes that generate harm were not reflected in accessible legal institutions. Resulting from the simplifications and hurdles inherent in legal processes, the corporation and corporate harm came to be conceived as more local than multinational or transnational.

What people expressly desired in the cases that Lindt describes was a public declaration of wrongdoing, as would be entailed in the judgement of a court, a public statement of who was at fault and therefore responsible. Since the absence of a judgement attributing fault also forestalls the creation of precedent, the two issues central to the plaintiffs' hopes in litigation - justice and the prevention of future harm - remain unachieved. 
As David Loher discusses, law abstracts not only from the spatial dimension of corporate harm production but also from their temporal dimension. In transnational lawsuits and regulatory developments targeting harms that result from business activities, the most common forms of temporal dimensions of law are forfeiture and limitation periods. Both these legal timeframes are recurring features in transnational lawsuits against corporations. ${ }^{6}$ In the criminal lawsuit against the Swiss proprietor of the parent corporation of an asbestos processing factory in northern Italy, Loher describes how the temporality imposed on a harm by a statute of limitations clashes both with the temporality of the substance, asbestos, and its lasting injuriousness, and with the perception of those still suffering the effects of the industrial activities years after their cessation. From the perspective of the law, the harmful activities came to an end with the closure of the factory. For the local residents, however, the harm is continuous and will continue into the foreseeable future. The timeframe of the injury, of suffering and of fearful anticipation of future harm, does not fit into the 'time-maps' (Gell 1992) of law.

Loher's interlocutors explicitly address the utterly unequal distribution of costs and profits: 'He made a fortune. And we should pay the price. Until today.' Responsibility here was demanded from those whose causative role in the harms suffered was under dispute, but who were nonetheless seen as the main beneficiaries of the activities that caused these harms. The responsibility of those perceived as benefitting from harmful activities was also considered to last as long as the effects of these activities were suffered.

These cases demonstrate the many obstacles legal suits must overcome to reach adjudication. When they - for whatever reason - move to the private forums of out-of-court settlements, they fail to attribute fault and establish who bears responsibility and they do not publicly affirm the norms violated by the events that caused harm. The awareness among affected people of the complex webs of actors that produce the harms that make them suffer leads them to engage in 'legal reasoning' that recalibrates the relations among causation, capacity, intent, command and profit for the attribution of responsibility. They seek to hold responsible to a greater degree those on whose behalf and to whose benefit activities that cause harm are undertaken. What we see in these lay reasonings are conceptions of responsibility that, while partial to the needs and sufferings of those concerned, take into account the relations of power, the acts and motives that drive capitalism. In that regard, they are more appropriate to the situations they experience than 
are the available legal instruments, which is why the latter often leave the affected people dissatisfied and disappointed.

Shifting attention from the law and transnational lawsuits to the subject of responsibility, the corporation as such, Laura Knöpfel identifies the potential of legal temporality to act as one of the 'cutting devices' of liberal law regarding relations between society and business. In her case, the temporality of law that regulates a business activity serves to reject ascriptions of responsibility in the present. The time-binding function of law thus concerns past injuries or obligations in the present, and is also relevant with regard to future, not yet materialized harms: The mining corporation in Knöpfel's example refers to the risks associated with the future closure as a means of fulfilling its present needs. A 'not-yet risk', such as high unemployment following the 'not-yet' closures of mines, becomes a means to distract from current demands for employment opportunities. She discusses how corporate managers turn their representation of time, time as closure, into a governance technique to navigate attributions of the responsibility of care. She enquires into the role of law in the strategic representation of time and asks how different legal orders of the multinational enterprise at a global resource frontier map onto that representation of time as closure.

This highlights how struggles around the harmful effects of the economic activities of multinational corporations can address only a specific range of harms and leave unaddressed issues such as poverty, the fear of unemployment and the loss of livelihood that Knöpfel's interlocutors express. They thus necessarily jar with the ambiguous relations that many people have with multinational corporations, which simultaneously encompass dependence, benefits and injuries. What becomes evident here is how responsibilities are complex in themselves and entail not only obligations to 'do no harm' but also broader responsibilities of care that arise from the asymmetric relations of interdependence between corporations and societies.

\section{Complicit states}

In transnational lawsuits and legislative regulatory developments regarding corporate responsibility in global economic relations, form, role, and responsibility of today's modern corporation are scrutinised, negotiated, and newly defined. At stake is the nature of the corporation, and thus an unsettled matter that has become an object of research for anthropologists. In 2010, the anthropologists Peter Benson and Stuart 
Kirsch complained that 'anthropologists pay more attention to the state and governmentality than to how corporations shape the world in accordance with their pursuit of profit, growth and legitimacy' (Benson and Kirsch 2010: 459). Since then, anthropologists have begun increasingly to explore 'corporate lives' and their role in the making of the contemporary world (Foster 2017; Li 2015; Rajak 2011; Welker 2014; Welker et al. 2011).

However, if we focus solely on corporations as the prime actors in these relations, we render invisible the fact that they are, to some degree, state-created entities. Even though corporations are now involved in drafting law (see, e.g., Mugler 2019) and international organizations such as the World Trade Organization (WTO) or the International Monetary Fund (IMF) - in which only some states have an effective say have developed their very own norm-generating formats, we would do well to take into account how states participate in the making of global capitalism. Formally, it is states that make the laws that regulate the global economy and give corporations their legal shape (Pistor 2019). It is, moreover, governments that choose which laws to enact how and when, even if some states are severely restricted in their choices of whether or not to ratify international agreements on legal forms. The fact that states differ in terms of their autonomy towards international treaties and agreements, as well as towards the legal strategies of corporations, should not deflect from the governmental decisions that create the specific relations between places, those who inhabit these places, and corporations. This is what Shalini Randeria (2003) meant by the 'cunning state': the state that capitalizes on its perceived weakness in order to avoid responsibility. The more states present themselves as weak, the more attention is focused on corporations. ${ }^{7}$

We see the importance of the role of the state regarding corporate responsibility and accountability reflected in the legal consciousness of the people affected by corporate activities. In her contribution to this issue, Laura Affolter follows the lawsuits brought against the Ecuadorian state for granting mining concessions to foreign investors. These claims are not directed against one individual mining corporation and do not seek remedy for a specific harm. Rather, they call into question the whole economic policy of the government of Ecuador. The constitutional action that Affolter explores aims at a structural change towards a regime in which investment and tax decisions would be guided by concerns for the liveability enshrined in the constitutional principle of buen vivir. Constitutional remedies bring together the spheres of politics and the economy and provide the means to address potential future 
'root causes' of harms. At stake in the case that Affolter discusses is thus not only the legal structure, but also the political and economic structures in which corporations are embedded.

Taken together, the articles in this special issue point to the political acts that enable specific practices and relations of production, trade, and consumption while disabling others. Since neither corporations nor any single state or international organization creates these structures of possibility independently and since there is not even any clear division of labour, the locations of responsibility are increasingly complex webs of entangled actors at different scales, encompassing corporations, legislatures, governments, and consumers. Considering all these various participants in the making of situations of injury and suffering foregrounds the political economy of harms. Legal and political acts, economic structures and corporate conduct condition and constitute each other.

\section{Towards new responsibilities}

In the struggles for justice discussed here, we detect potential ways of rethinking ascriptions of responsibility to reflect the deep entanglements of our current world. These entanglements engender inextricable 'communities of responsibility' (Eckert 2016) formed by our participation in the long chains of distributed action constituted by global capitalism. Those engaged in struggles are aware that diverse connected deeds cause suffering, and they claim that those who could have but did not prevent a case of harm should also be held responsible and liable. They renegotiate what today in law is called mediate responsibility: actions and omissions that enable (rather than physically cause) situations of damage and hurt. These are moving closer to the centre of claims (Eckert 2019). They also put a new focus on those that benefit from harmful activities, whether intentionally or not. ${ }^{8}$ Their benefits, as the ultimate end of the economic activities that generate harm, are re-conceptualized as primary 'causes' of harm. By moving actors and activities that enable and benefit from corporate harm to the fore, the legal institution of causation in criminal and civil law becomes secondary to determine attributions of responsibility and liability.

Current legal instruments also contain principles that make omissions, failure to provide assistance, and forms of mediate responsibility such as aiding and abetting, or complicity (hovering between direct and indirect responsibility) punishable. However, the distinction between 
mediate and immediate responsibility, that is, the specific narration of causation implicit in these terms, does not correspond to the processes that constitute factual entanglement and harm in global entanglements; the distinction reproduces the divisions among primary and secondary causative actions set by jurisdictions. Moreover, aside from problems associated with jurisdictional borders and separate corporate personalities, the inability of current legal instruments to grapple with responsibility for harms that occur in global value chains lies in the weight they give to immediate cause, intent, and the capacity to effect change, which Bernard Williams (1993) called 'response'. Reconceiving responsibility as a matter of 'complex networked associations', as Manzurual Hassan, Peter Atkins, and Christine Dunn (2006: 280) have proposed, challenges us to reconsider the links between legal norms of responsibility, notions of causation and issues such as capacity (to change), intent, and response inherent in concepts of responsibility, and consider each in a more relational manner, weighing capacity and intent within these entanglements in a way that reflects the different capabilities of all participants 'to act otherwise'.

We see suggestions of this in the claims people make on different actors: The claims to obligations of care made by Laura Knöpfel's interlocutors; the insistence of the people David Loher encountered that those who profit bear responsibility whether or not they are the immediate cause of harm and that they bear responsibility as long as the injuries caused by the activities that they benefitted from continue to occur; the claims to prospective responsibility of state agents in the struggles Laura Affolter describes, prospective responsibility for not only the prevention of individual harms but more generally for safeguarding the possibility of living well (buen vivir) for humans and non-human nature alike; and, last but not least, the insistence of the communities in Angela Lindt's cases that justice is a public issue, not to be individually dispersed in private settlement agreements. These instances of lay 'legal reasoning' suggest ways of attributing responsibility that may more appropriately reflect the relations of power that shape our current world. ${ }^{10}$

The ways our interlocutors imagine and articulate corporate responsibility entail suggestions about the question raised by James Ferguson about how a unit of responsibility can be identified in entangled, global relations. These struggles, legal and at the same time profoundly political, call us to enquire further how institutions of graduated liability that neither diffuse responsibility entirely into vague notions of political or ethical responsibility nor abandon limits to (individual, 
corporate, and collective) legal responsibility could be established. How could the 'bottom up' perspectives on corporate responsibility that we have found in our empirical enquiries into the relations between business and society at resource frontiers as well as in the distinct lawsuits against corporations and states for transnational harms to people and the environment alter and adapt legal concepts such as causation, separate corporate personality, and limited liability to reflect more adequately the economic, political, and social reality of transnational business relations? In particular, how might we legally grasp the acts and omissions that enable and the actors that benefit from transnational apparatuses of harm production? And finally, how might we think about causation if we were to foreground the capacity of actors to prevent systems of harm to emerge, or at least to ameliorate them, and to remedy losses and injuries? Would this take into account, in establishing obligations of care and remedy, the benefits that accrue to some - and some more so than others - from harmful activities? These are the questions that arise from this special issue's studies of struggles for legal, moral and political corporate responsibility.

Julia Eckert is Professor for Political Anthropology at the University of Bern. Her research explores the relation between moral and legal norms, and institutions of responsibility and participation. Her publications include: The Charisma of Direct Action (2003); The Social Life of Anti-Terrorism Laws (2008); Law against the State (2012). She is co-editor of Anthropological Theory. Email: julia.eckert@anthro.unibe.ch

Laura Knöpfel is Research Fellow and PhD candidate at the Transnational Law Institute of the Dickson Poon School of Law of King's College London. She works on a legal anthropology of the multinational enterprise. Email: laura.knopfel@kcl.ac.uk

\section{Notes}

1. In response to Bruno Latour's thesis on the extension of the chains of action in the modern age, Marilyn Strathern held that while modern networks or action chains have possibly become more far-reaching, modern institutions, such as modern law, cut short these networks at intervals briefer than many traditional norms.

2. In the following, we use the concept of the 'global value chain' to describe border-transcending economic processes structured by equity or contract. The concept of the global value chain is to be situated in the notion of the 'commodity 
chain' that Terence Hopkins and Immanuel Wallerstein developed in the course of their world-systems research in the 1970s and 1980s (Hopkins and Wallerstein 1977, 1982) to describe the integration of production 'on a world scale'. They described the multinational corporation as 'an accumulating production unit' transferring capital from the periphery to the core (Hopkins and Wallerstein 1982: 79-80) in a process of 'world accumulation'. Whereas the concept of the commodity chains seeks to describe the macro dynamics in the world system, the notion of the global value chain centres on the governance of the relations and processes between linked firms (Bair 2008). Global value chains describe the value-adding processes that involve different firms and the entirety of activities required to conceive, extract, manufacture, sell, trade, consume, and recycle a product (Gereffi and Fernandez-Stark 2016). Of course, the notion of 'value' is highly problematic, since it is based on a limited notion of value understood in purely monetary and financial terms (Gradin 2016). This is especially problematic with regard to natural resources. Natural resources only appear in official national accounts after they have been exploited commercially. As Thomas Piketty argues, this distorts the real growth of national income or GDP since extraction 'depletes existing reserves while contributing to air pollution and global warming, neither of which is reflected in official national accounts' (Piketty 2020: 612).

3. The UN Global Compact, established and launched by UN SecretaryGeneral Kofi Annan in 2000, marks the beginning of decentralized, multilevel, and normatively plural governance of corporate social responsibility. To date, the UN Global Compact is the world's largest voluntary initiative, bringing together over 13,000 corporations. It comprises ten principles in the areas of human rights, labour rights, and the environment. However, it should be noted that efforts to establish an international regulatory framework to govern the activities of multinational corporations go back to the 1970s. While an UN initiative to develop binding rules was unsuccessful and formally abandoned in 1992, the Organisation for Economic Co-operation and Development adopted a set of Guidelines for Multinational Enterprises in 1976, and the International Labour Organization followed a year later with the adoption of a Tripartite Declaration of Principles Concerning Multinational Enterprises. Both regulatory frameworks make reference to the Universal Declaration of Human Rights, and the OECD Guidelines have since incorporated the UN Guiding Principles of Business and Human Rights. Since the end of the 1990s, the pace of regulatory action has accelerated in an unprecedented manner.

4. The majority of lawsuits have been filed under the usual rules of tort law and the law of delicts with the claim that the parent corporation has either a direct duty of care or is vicariously liable for damages resulting from human rights violations and environmental pollution linked to its business activities.

5. The UN Guiding Principles of Business and Human Rights speak of businesses' responsibility to respect human rights and introduce the idea of human rights due diligence. They represent a turning point in the governance of businesses' transnational responsibilities. Having called on nation states to regulate the conduct of 'their' corporations, various governments have adopted or are in the process of developing laws that take up the idea of human rights due diligence. In particular, the French law on the duty of vigilance, the EU Directive on the reporting on non-financial information and the Dutch child labour law should be mentioned. 
6. In transnational lawsuits, these statutes of limitation are exacerbated in their effect by the time it takes for claims to travel from the periphery to the core of global value chains. To say it in the simplest way possible: the preparation of a transnational lawsuit requires a lot of time and therefore always risks being time-barred before a first-instance judgement is achieved.

7. As is evident in Laura Knöpfel's article, it is not only states but also corporations that engage in 'acts of cunning' in order to render themselves unaccountable. We need to recognize misrepresentations of weakness and move beyond state or corporate self-descriptions of their positionality within global entanglements.

8. Iris Marion Young already questioned the adequacy of liability models that rely on direct relations of cause and effect. She found them unsatisfactory and pointed to the obligations of those involved in the broader chain of events in which harms are produced, even when they are pursuing goals and interests within given institutional rules and accepted norms (2011). Even earlier, Judith Shklar (1990) put forth the suggestion that responsibility can do without the concept of the moral agent or the autonomous individual and focus instead on the capacity to mitigate suffering.

9. For the ability to act otherwise as a pre-condition of bearing responsibility, see for example, Laidlaw 2014.

10. We take inspiration here from Maksymilian del Mar, who argues that legal reasoning provides new possibilities of interpretation 'hinting at the possibility, perhaps even desirability ... of introducing, more explicitly, a new rule in the future' (Mar 2017: 51).

\section{References}

Bair, J. (2008), 'Global Commodity Chains: Genealogy and Review', in J. Bair (ed), Frontiers of Commodity Chain Research (Stanford, CA: Stanford University Press), 1-34.

Beck, U. (1999), World Risk Society (Cambridge: Polity Press).

Benson, P. and S. Kirsch (2010), 'Capitalism and the Politics of Resignation', Current Anthropology 51, no. 1: 459-486.

Burgos, S. (2012), 'Corporations and social responsibility: NGOs in the ascendancy', Journal of Business Strategy 34, no. 1: 21-29.

Eckert, J. (2016), 'Tugend, Recht und Moral: Tendenzen der Verantwortungszuschreibung' [Translation here Virtue, law and morality: trends in attributions of responsibility], Deutsche Zeitschrift für Philosophie 64, no. 2: 246-257.

Eckert, J. (2019), 'The morals of liability: Some thoughts on "Humanitarians in court"', Journal of Legal Pluralism and Unofficial Law 50, no. 3: 375-378.

Eckert, J., B. Donahoe, C. Strümpell and Z. Ö. Biner (2012), 'Introduction: Laws travels and transformations', in J. Eckert, B. Donahoe, C. Strümpell and Z. Ö. Biner (eds), Law against the State: Ethnographic Forays into Laws Transformations (Cambridge: Cambridge University Press), 1-22.

Ferguson, J. (2012), 'Structures of responsibility', Ethnography 13, no. 4: 558-562.

Foster, R. (2017), 'The corporation in anthropology', in G. Baars and A. Spicer (eds), The Corporation - A Critical, Multi-Disciplinary Handbook (Cambridge: Cambridge University Press), 111-133. 
Gell, A. (1992), The Anthropology of Time: Cultural Constructions of Temporal Maps and Images (Oxford: Berg).

Gereffi, G. and K. Fernandez-Stark (2016), Global Value Chains Analysis: A Primer, 2nd ed. (Durham, NC: Duke University Centre on Globalization, Governance \& Competitiveness).

Gradin, S. (2016), 'Rethinking the notion of "value" in global value chains analysis: A decolonial political economy perspective', Competition $\mathcal{E}$ Change 20, no. 5: 353-367.

Hassan, M. M., P. J. Atkins and C. E. Dunn (2006), 'Toxic torts: Arsenic poisoning in Bangladesh and the legal geographies of responsibility', Transactions of the Institute of British Geographers 31, no. 3: 272-285.

Hopkins, T. and I. Wallerstein (1977), 'Patterns of development of the modern world-system', Review Fernand Braudel Center 1, no. 2: 111-145.

Hopkins, T. and I. Wallerstein (1982), World-Systems Analysis: Theory and Methodology (Beverly Hills, CA: SAGE Publications).

Joerges, C. and J. Falke (eds) (2011), Karl Polanyi, Globalisation and the Potential of Law in Transnational Markets (Oxford: Hart Publishing).

Kirsch, S. (2014), Mining Capitalism: The Relationship between Corporations and Their Critics (Berkeley: University of California Press).

Laidlaw, J. (2014), The Subject of Freedom; An Anthropology of Ethics and Freedom (Cambridge: Cambridge University Press).

Lemaitre, J. (2007), 'Legal fetishism at home and abroad', Unbound 3, no. 6: 1-20.

Li, F. (2015), Unearthing Conflict: Corporate Mining, Activism, and Expertise in Peru. (Durham, NC: Duke University Press).

Mann, I. (2017), 'Maritime legal black holes: Migration and rightlessness in international law', European Journal of International Law 29, no. 2: 347-372.

Mar, M. (2017), 'Legal Reasoning in Pluralist Jurisprudence', in N. Roughan and A. Halpin (eds), In Pursuit of Pluralist Jurisprudence (Cambridge: Cambridge University Press), 40-63.

Marks, S. (2011), 'Human rights and root causes', Modern Law Review 74, no. 1: 57-78.

Marx, A., C. Bright, and J. Wouters (2019), Access to Legal Remedies for Victims of Corporate Human Rights Abuses in Third Countries (Brussels: European Parliament).

Mugler, J. (2019), 'Regulatory capture? Fiscal anthropological insights into the heart of contemporary statehood', The Journal of Legal Pluralism and Unofficial Law 50, no. 3: 379-395.

Nolan, J. and D. Baumann-Pauly (eds) (2016), Business and Human Rights: From Principles to Practice (Oxon: Routledge).

Ong, A. and S. Collier (eds) (2005), Global Assemblages: Technology, Politics, and Ethics as Anthropological Problems (Malden, MA: Blackwell Publishing).

Palombo, D. (2020), Business and Human Rights: The Obligations of the European Home States (Oxford: Hart Publishing).

Piketty, T. (2020), Capital and Ideology (Cambridge, MA: The Belknap Press of Harvard University Press).

Pistor, K. (2019), The Code of Capital: How the Law Creates Wealth and Inequality (Princeton, NJ: Princeton University Press).

Rajak, D. (2011), In Good Company: An Anatomy of Corporate Social Responsibility. (Stanford, CA: Stanford University Press). 
Randeria, S. (2003), 'Cunning states and unaccountable international institutions: Legal plurality, social movements and rights of local communities to common property resources', European Journal of Sociology / Archives Européennes De Sociologie / Europäisches Archiv Für Soziologie 44, no. 1: 27-60.

Rodríguez-Garavito, C. (ed) (2017), Business and Human Rights: Beyond the End of the Beginning (Cambridge: Cambridge University Press).

Ruggie, J. G. (2007), 'Business and human rights: The evolving international agenda', The American Journal of International Law 101, no. 4: 819-840.

Ruggie, J. G. (2013), Just Business: Multinational Corporations and Human Rights (New York: W. W. Norton \& Company).

Shklar, J. (1990), Faces of Injustice (New Haven, CT: Yale University Press).

Skinner, G., R. McCorquodale, O. D. Schutter and A. Lambe, (2013), 'The third pillar: Access to judicial remedies for human rights violations by transnational business', ICAR, CORE and ECCJ, https://corporatejustice.org/documents/ publications/eccj/the_third_pillar_access_to_judicial_remedies_for_human_ rights_violation.-1-2.pdf (accessed 7 November 2020).

Sobel-Read, K. B. (2014), 'Global value chains: A framework for analysis', Transnational Legal Theory 5, no. 3: 364-407.

Strathern, M. (1996), 'Cutting the network', Journal of the Royal Anthropological Institute 2, no. 3: 517-535.

Welker, M., D. Partridge and R. Hardin (2011), 'Corporate lives: New perspectives on the social life of the corporate form', Current Anthropology 52, no. S3: 3-16.

Williams, B. (1993), Shame and Necessity (Berkeley: University of California Press)

Young, I. M. (2011), Responsibility for Justice (Oxford: Oxford University Press).

Zerk, J. (2015), Corporate Liability for Gross Human Rights Abuses: Towards A Fairer and More Effective System of Domestic Law Remedies. A Report Prepared for the Office of the UN High Commissioner for Human Rights (Geneva: Office of the UN High Commissioner for Human Rights). 